\title{
Evaluation, Temporality, Numerical Skill and Daily Mathematics Operations as Factors That Explain Anxiety toward Mathematics on High School Students: An Empirical Study in Tuxtepec-Oaxaca, México
}

\author{
Elena Moreno-García ${ }^{1}$, Arturo García-Santillán ${ }^{2} \&$ Celia Cristóbal-Hernández ${ }^{3}$ \\ ${ }^{1}$ School of Economics, Universidad Cristobal Colon, Campus Calasanz, Veracruz, Mexico \\ ${ }^{2}$ Administrative-Economic Research Center, Universidad Cristobal Colon, Campus Calasanz, Veracruz, Mexico \\ ${ }^{3}$ Doctoral Program in Management Science at Universidad Cristobal Colon, Veracruz, México \\ Correspondence: Arturo García-Santillán, Administrative-Economic Research Center, Universidad Cristobal \\ Colon, Calle: Tulipán No. 50, Suite 407 Fracc. Jardínes del Virginia, Boca del Río, Veracruz C.P. 94294, México. \\ Tel: 22-9-923-2950 to 53; Ext. 6285. E-mail: arturogarciasantillan@yahoo.com.mx
}

Received: February 21, 2014 Accepted: April 3, 2014 Online Published: May 26, 2014

doi:10.5539/ass.v10n12p79 URL: http://dx.doi.org/10.5539/ass.v10n12p79

\begin{abstract}
The aim of this research was to measure anxiety toward mathematics on Jr. High School students from Tuxtepec, Oaxaca, Mexico. It was utilized the Muñoz and Mato (2007) (Note 1) anxiety scale to analyze five dimensions of anxiety, anxiety toward: evaluation, temporality, understanding problems, number operations and math situations of real life. 509 questionnaires were random applied face to face to boys and girls students of all high school's degrees. The statistical procedure utilized was the factorial analysis with principal component extracted. Results obtained allow us to know that variables related to the understanding of mathematical problems and evaluation have the biggest contribution to explain variance of the phenomenon studied.
\end{abstract}

Keywords: evaluation, temporality, numerical skill, mathematics anxiety

\section{Introduction}

\subsection{Statement of Problem}

Main indicators of school performance in the European Union were obtained through two types of evaluations, the PISA test (Program for International Student Assessment) and TIMSS test (International Study of Trends in Mathematics and Science). Results of these tests allow us to see the concern because of the lack of progress in many Europeans countries in such important discipline as mathematics, considered a key to achieve countries development, which is evident in the Eurydice network's report (2011) called "teaching of mathematics in Europe, common challenges and national policies", because one of the objectives for 2020 is that 15 years old people with an insufficient level of competence in reading, math and science must be less than $15 \%$.

TIMSS test for European countries focus on four levels and a maximum score of 625 points, with an average score of 519 points. In 2011, this test's result showed that countries like Australia, Italy, Spain and Poland were below average (519 points), in total, 22 of 35 countries were below average. About levels, 19 countries were on level three (54\%), 14 countries were on level two, (40\%) and only two countries were in the optimal level of one $(6 \%)$. In the last PISA test's report (2012), countries from European Union were located below the average of the Organization for Economic Cooperation and Development (OECD) with 489 points of 494, but countries like Spain, Portugal and Italy had a score even below.

The Latin American countries, Chile and Mexico, members of the OECD, occupied the last places of the PISA test (2012). Mexico in particular got a score of 413 points in mathematics, when the average score is 494. Mexico presented a relapse respect the previous 2009 test when it gained 419 points in mathematics test.

In Mexico, there is a basic academic evaluation called ENLACE (National Assessment of Academic Achievement in Schools). 78.1\% of the secondary schools that were evaluated in 2013 got an "insufficient and elemental" level, while only $21.9 \%$ were "good to excellent". In the state of Oaxaca, "good to excellent" level 
was reached only by $4.7 \%$ schools. This situation motivates the analysis that could explain why the level of learning in mathematics is so low, especially in some regions of the southeast of Mexico, because there is evidence that it is a global problem but the situation is more serious in some regions of the third world. In addition, some variables have showed that the cause of the problem is not only cognitive, but there is an important implication about emotional anxiety toward mathematics.

The EURYDICE network's report (2011) try to explain the phenomenon of low performance in tests, highlighting the concept "motivation" and distinguishing intrinsic motivation of extrinsic motivation (Deci \& Ryan, 1985). Intrinsic motivation leads to self-efficacy, which predicts the ability to succeed (Bandura, 1986), and in the area of math, self-efficacy is a predictor of academic performance (Mousoulides \& Phillippou, 2005; Pintrich, 1999), in this way, motivation is related with student's self-esteem, their stress and anxiety, among other concepts (Lord et al., 2005). Therefore, in European Union, anxiety toward mathematics is part of the context of a problem to be solved even in countries with yields above the levels of other countries, such as Latin American countries.

In Mexico, the results of the tests ENLACE and PISA are indicators of the poor performance in core subjects like Spanish and math, which puts on the political agenda the importance and relevance of this subjects, especially mathematics in education. To find the cause of poor performance in mathematics has been a topic of several researches, some studies reveal that the problem is emotional (Mandler, 1989), (Mc Leod \& Adams, 1989); and other that it is attitudinal (Fennema \& Sherman, 1976, 1978), (Whitley, 1979); (Garcia-Santillán, Venegasy, \& Escalera, 2013); (Escalera, García-Santillany, \& Venegas, 2013); (Garcia-Santillan et al., 2012).

All these researches have a consensus about anxiety toward mathematics and the negative effect it has on students. According to Akey, (2006), this anxiety and the incidence of attitudes in mathematical performance of high school's students have a positive correlation, and Auzmendi (1992) said that students learn better something that produce them pleasure, therefore, a negative attitude is correlated with a low performance (Aliaga \& Chest, 2000), and with high levels of anxiety (Magalhaes, 2007). Persons with strong anxiety drives are prompted by habit to reenact their task-irrelevant behaviors that impair performance (Belbase, 2010). This problem derives in various phenomenon, some as drastic as the evasion of subsequent courses of mathematics (Hancock, 2001) because according to Watt (2000), the problem increase as much as students increase levels of studies. With the above arguments it is necessary to propose the preliminary research question and objective:

What variables explain the level of anxiety toward mathematics in high school students from Tuxtepec, Oaxaca?

Therefore, the aim of this research is to measure anxiety toward mathematics on high school students from Tuxtepec, Oaxaca, Mexico.

\section{Review of the Literature}

In the last two decades, there have been increases of publications that relate the affective dimension of the individual (beliefs, attitudes, and emotions) and the teaching and learning mathematics process (Gairin, 1990; Miranda, Fortes, \& Gil, 1998; Mcleod, 1992, 1994; Schoenfeld, 1992; Gomez- Chacón, 1997, 1999, 2000).

Attitude toward mathematics has been a subject of researchers from many countries, and a significant majority considers that affective in math's teaching is a priority. This kind of 'anxiety' is first detected in the late 1950s. Dreger and Aiken (1957); noticed undergraduate college students reacting emotionally to arithmetic and mathematics (Karimi \& Venkatesan, 2009). Watt (2000) obtained results which show that there is a relationship between attitude and academic performance, and that this relationship is increasingly prevalent in a negative way, by what to a higher level of education, the greater the negative attitude to the learning of mathematics. On the other hand, it is important that students choose their career in function of his vocation and not by an appreciation that have on a matter. Recent studies found that, as a student moves from elementary education to high school, their attitude toward mathematics becomes more negative (Utsumi \& Mendez, 2000).

A negative attitude toward mathematics may play an important role in the outcome that finally is reached (Polya, 1945). An example of this conclusion is given when students avoid taking math courses (Fennema \& Sherman, 1976; Ho et al., 2000; Richardson \& Suinn, 1972; Tobias \& Weissbrod, 1980) and later, when students must choose a university to study their career; their options are limited because they try to avoid courses that integrate mathematics. These years are also recognized as a crucial period in the development of students' mathematical understanding: it is well known that rational number concepts, particularly fractions, present difficulties for many middle school students and that students' lack of competence with fractions is a major influence on their overall mathematics competence (Siemon, Virgona, \& Cornielle, 2001; in Jennison \& Beswick, 2010).

Gender studies also provide important findings that should be considered in the analysis of anxiety toward 
mathematics. Investigations about elementary and secondary students, even about adults, shows that girls are more susceptible to physical symptoms as: nerves, tension, discomfort (Wigfield \& Mecce, 1988). Although Perina (2002) questioned this claim arguing that women are more open to admit anxiety toward mathematics than men.

Piaget's theory stipulates that since its birth, a child builds knowledge by means of a dialectical process by interaction with the surrounding world, but the numerical sense does not begin until the four or five years, however, Gdansk (1954) with a new theory proclaims the existence of cognitive powers innate in the human brain. Then, the learning of mathematics does not start as Piaget conceived, but through a bi-directional mechanism one aware and the other unconscious. In the mind of the child encodes concepts through the language and memorization of numerical algorithms and the unconscious, where there are the faculties' photo-numerical, collects the first numeric elementary knowledge.

If the theory of Dantzig (1954) is correct, it would explain why students lose motivation and mathematics for them results difficult and tedious, since programs of study are based on abstract concepts and the memorization of tables, in place of the use of graphics and construction of mental models (Dehaene, 1997).

Attitude, as psychological predisposition of a behavior translates loss of motivation into an unfavorable disposition toward mathematics; on the other hand, when there is high level of motivation the provision is favorable. Recent studies (Escalera, García-Santillán, \& Venegas, 2014) show that in attitude of students toward statistics there are two factors that explain the phenomenon; the first one with three favorable indicators (utility, anxiety, confidence) and the second one with two unfavorable indicators (anxiety and motivation). In their findings, these authors refers that students see the usefulness of statistics in the professional field, which makes them to like the topic, which in turn generates confidence to learn what in theory translates into motivation.

The measurement of this attitude requires defining concepts that will make up the items and determine their dimensions. Among the pioneering designs, is the numeric anxiety scale designed by Dreger and Aiken, (1957), the scale of assessment of mathematics anxiety, (MARS-The Mathematics Anxiety Rating Scale), designed by Richardson and Suinn (1972), the scale to measure attitudes of mathematical designed by Fennema and Sherman, (1976), the scale anxiety toward mathematics of Sandman (1980) and the questionnaire of mathematical anxiety of Wigfield and Meece, (1988) and most recently, the scale to measure math anxiety in students of secondary compulsory education, designed by Muñoz and Mato (2007).

The questionnaire of Muñoz and Mato, with overall reliability $\alpha=0.9504$ consists of 24 Likert items integrated by five factors: Anxiety toward evaluation (ANSIEVAL), Anxiety toward temporality (ANSIETEM), Anxiety toward understanding of mathematical problems (ANSIECOM), Anxiety toward numbers and math operations (ANSIENUM) and Anxiety when faced with situations real-life math (ANSISIMA). These authors took as reference the Mathematics Anxiety Rating Scale (MARS) composed of 98 items and designed by Richardson and Suinn (1972).

All these theoretical and empirical arguments lead us to the research question of the study: "RQ $\mathrm{Q}_{1}$ which is the set of latent variables that explain student anxiety toward mathematics in Jr. High School students from Tuxtepec, Oaxaca?" the objective is: $\mathrm{O}_{1}$ : Identify latent variables that explain students' anxiety toward mathematics. Thus, we seek to test Hi: There are a set of latent variables or factors that explain students' attitude toward mathematics.

\section{Methodology}

This research is not experimental because variables were not manipulated, is transverse considering that data obtained was performed in a single moment of the study. 509 students were surveyed in all three levels of study in five secondary schools in Tuxtepec, Oaxaca, Mexico. The instrument used is the scale designed by Muñoz and Mato (2007). This test was designed to measure math anxiety, therefore, it was proposed for this study. This instrument integrates 24 indicators (items) that comprise five dimensions of anxiety: The factor "anxiety toward evaluation" comprises 11 items, the factor "anxiety toward temporality" includes 4 items, the factor "anxiety toward the understanding of mathematical problems" with 3 items, the factor "anxiety toward numbers and math operations" which includes 3 items and the factor "math anxiety situations of real life" that includes 3 items."

Each dimension is detailed in the following Table 1. 
Table 1. Dimensions of anxiety toward mathematics scale

\begin{tabular}{lll}
\hline Code & Dimensions & Items \\
\hline ANSIEVAL & Anxiety toward evaluation & $1,2,8,10,11,14,15,18,20,22,23$ \\
ANSIETEM & Anxiety toward temporality & $4,6,7,12$ \\
ANSIECOM & Anxiety toward understanding mathematical problems & $5,17,19$ \\
ANSIENUM & Anxiety toward the number and operations & $3,13,16$ \\
AMSISIMA & Anxiety toward real life situations & $9,21,24$ \\
\hline
\end{tabular}

Source: take it from Muñoz and Mato Scale (2007)

Values at likert scale means: $1=$ nothing $(\mathrm{SN}) 2=\mathrm{A}$ few times $(\mathrm{PV}), 3=$ Neutral (Neutral) $4=$ Most times (LMV), 5 = Always Much (SM).

Individual interviews were conducted with each participant prior to their daily classes. All statements were readied to each participant to determine his perception about situations around math understanding as well as their feelings "nervousness" about the topic. Statements were like "I feel nervous about math test" or "I feel nervous when I see my math professor explaining a math problem".

The characteristics of this questionnaire are in concordance with the aim of this research due to the importance of mathematics and the role that play on student's academic and professional performance. Hence, it becomes very relevant to obtain prior information on this phenomenon in order to guide the learning objectives of subject content of mathematics. Therefore, this questionnaire could be utilized so much: as an evaluation platform that allows most effective decision-making, as a preventive measure to help specific treatments towards students or instructional changes in the classroom, all this, with the intention to improve attitudes, emotions and fears to activities related to math.

\subsection{Statistical Procedure}

For evaluation and interpretation of the data collected we follow the statistical procedure of multivariate factorial analysis proposed by García-Santillán, Escalera-Chávez and Venegas Martínez (2013). For this, we established the following criterion: Statistical hypothesis: Ho: $\rho=0$ there is no correlation Hi: $\rho \neq 0$ there is a correlation. The statistical test is $\chi^{2}$ and the Barlett's test of sphericity KMO (Kaiser-Meyer-Olkin), and aditionally the value of MSA (Measure sample adequacy) for each variable of model. This statistical is asymptotically distributed with $\mathrm{p}(\mathrm{p}-1) / 2$ freedom degrees, a significance level: $\alpha=0.01, p<0.01$ or $<0.05$ load factorial of 0.70 ; and loads increased to 0.55 .

In order to measure data obtained, we follow the procedure proposed recently by García-Santillán et al. (2013) and obtains the following matrix (Table 2).

Table 2.

\begin{tabular}{|c|c|}
\hline Students & Variables \\
\hline 1 & X11 X12 ...X1p \\
\hline 2 & $X 21 X 22 \ldots . X 2 p$ \\
\hline$\ldots$ & $\ldots \ldots$ \\
\hline 509 & Xn1 Xn2 ... .Xnp \\
\hline
\end{tabular}

With the above mentioned, now it shows the follow empirical result.

\section{Data Analysis}

\subsection{Test Reliability}

To analyze data obtained from the questionnaires, a reliability test was performed using Cronbach's alpha coefficient $(\alpha)$. This coefficient is not a statistical test but is a coefficient of reliability of internal consistency which takes values between 0 and 1 , which verifies whether the information gathered is inadequate or defective and could be lead to false conclusions otherwise be reliable and stable measurements may be made.

The closer it gets to 1 , is better reliability, considering that starting from 0.80 is a very acceptable value. Thus, the Cronbach's alpha can be set as a function of the number of items and the average of correlations among them (Hair, 1999). Therefore, it allows us to check if the instrument is reliable by the following formula: 


$$
\partial=\frac{\mathrm{N} * \overline{\mathrm{r}}}{1+(\mathrm{N}-1) * \overline{\mathrm{r}}}
$$

Where:

$\mathrm{N}=$ Number of items (or latent variables), $\bar{r}=$ average correlation between the items.

The results of processed cases are shown in Table 3 .

Table 3. Statistical reliability

\begin{tabular}{llll}
\hline Cronbach's Alpha & N cases & $\%$ & Alpha \\
\hline Cases Valid & 509 & 100.0 & $\alpha=0,945$ \\
Excluding(a) & 0 & & 24 Items \\
Total & 509 & 100.0 & \\
Grouped & ANSIEVAL, ANSIETEM, ANSIECOM, ANSIENUM & $\alpha=0,834$ \\
& ANSISIMA & 5 Elements
\end{tabular}

a. List wise deletion based on all, variables in the procedure

Source: own

The result obtained from 0.945 (expanded) and 0.834 (grouped) is quite acceptable considering the criterion $A C>0.6$ (Hair, 1998), thus, we can say that the instrument meets the characteristics of consistency and reliability required for this case; indicating a high reliability of scale (Muñoz \& Mato, 2007).

\subsection{Data Analysis}

The following histograms show the main characteristics about population of study, like: gender, and semester or grade, and after this, we show the result from the factorial analysis with extracted components rotated.

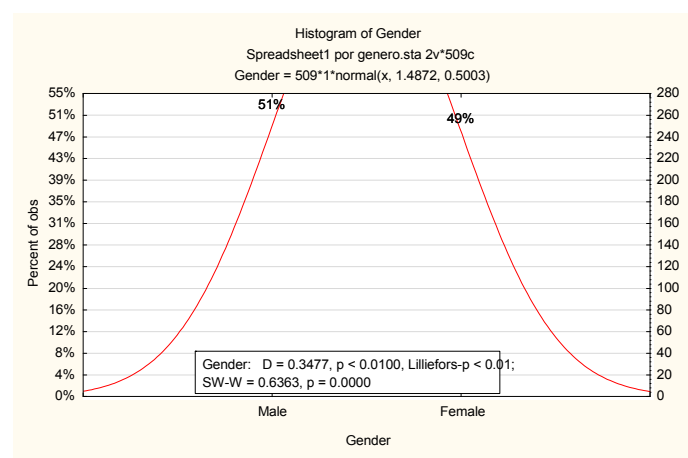

Figure 1. Gender

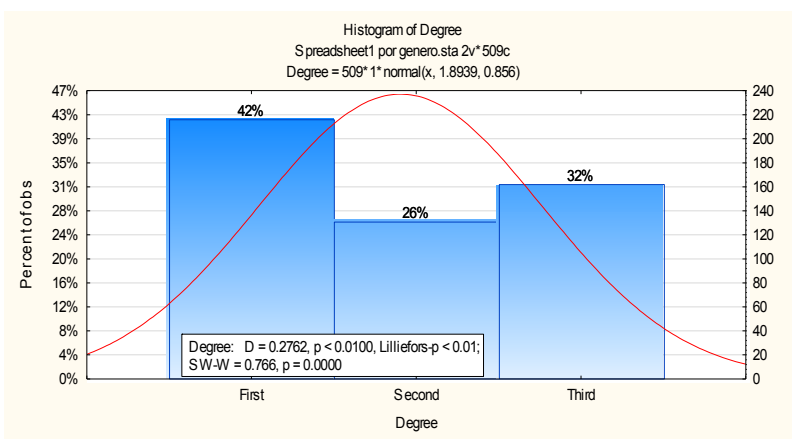

Figure 2. Grade

As a summary: we can see on the graphs that gender variable was equilibrated with $51 \%$ (male) and $49 \%$ (female). About student's degrees: $42 \%$ were in the first grade, $26 \%$ in second grade and the remaining $32 \%$ in third year.

To make sure that the procedure factorial analysis which was applied in this case is appropriate and that contributes to explain the phenomenon of study, the Bartlett test of Sphericity with KMO, and the measure of sample adequacy of each variable (MSA) was performed, with the aim to identify whether there is any correlation among variables that are being studied and allow us justify the use of this technique.

We must remember that, Bartlett test of Sphericity is a statistic used to test the null hypothesis, which states that the correlation matrix is an identity matrix, that presents a variation across 0 and 1 , and small values demonstrate that factor analysis is not appropriate because correlations between pairs of variables could not be explained by other variables. If there were lack of strong correlations between variables the factorial model would not be suitable, if the value in KMO is $<0.5$ (García-Santillán, Venegas, \& Escalera, 2013). 
Therefore, table 3 shows results of the Bartlett test of Sphericity, $K M O, X^{2}$, with significance $(\mathrm{p}<0.01)$. Observed values $X^{2}$ (2036.245 with $10 \mathrm{df}$ ) shows that are high, the measure of sampling adequacy (overall) KMO (0.883) is located in the rank of acceptance because, this should be higher than 0.5 , indicating that the variables are inter-correlated.

Table 4. Bartlett's test of sphericity

\begin{tabular}{lll}
\hline Measure of sampling adequacy Kaiser-Meyer-Olkin & & 0.883 \\
& Chi-square approximate & 2036.245 \\
Bartlett Test of Sphericity & df & 10 \\
& Sig. & 0,000 \\
\hline
\end{tabular}

Source: own.

Table 4 shows the values of correlations obtained from the variables studied, where it is possible to see that they are all inter-correlated and correlation among variables presents high values $(>0.05)$ in all the cases, which leads us to think that there is a concordance among the set of variables in the model, practice as well as statistics, which means, that factorial analysis is appropriate.

Table 5. Correlation matrix

\begin{tabular}{llllll}
\hline Variables & ANSIEVAL & ANSIETEM & ANSIECOM & ANSIENUM & ANSISIMA \\
\hline ANSIEVAL & 1.000 & & & & \\
ANSIETEM & 0.800 & 1.000 & & & \\
ANSIECOM & 0.758 & 0.722 & 1.000 & 1.000 & \\
ANSIENUM & 0.814 & 0.770 & 0.773 & 0.625 & 1.000 \\
AMSISIMA & 0.589 & 0.629 & 0.689 & & \\
\hline
\end{tabular}

Source: own. Determinant 0.018

Moreover the value of the determinant (0.018) is lower than 0.05 what also gives evidence of the presence of significant correlations in the set of variables studied. With transformation of the correlation matrix determinants, it was obtained Bartlett's test of Sphericity as it was shown in table 3, and is given by the following equation (2):

$$
d_{R}=-\left[n-1-\frac{1}{6}(2 p+5) \ln |R|\right]=-\left[n-\frac{2 p+11}{6}\right] \sum_{j=1}^{p} \log \left(\lambda_{j}\right)
$$

Another difference is the measure of sampling adequacy (MSA). Values of table 5, reveals that each variable exceeds the threshold value of 0.5 , this indicate the strength of relationships among variables and therefore that factorial analysis is appropriateness.

In the diagonal of anti-image correlation matrix, may be observed measures sampling adequacy for every variable (MSA). To determine if the selected factorial model is appropriate to explain the information collected, values in the diagonal of anti-image matrix should, have a value close to 1.00 , hence, the correlation coefficients anti-image that appear in diagonal, range from $0.856^{\mathrm{a}}$ to $0.901^{\mathrm{a}}$, therefore, are significant and it is confirmed that factorial analysis it is optimal to explain the phenomenon studied.

Table 6. Anti-image matrix

\begin{tabular}{llllll}
\hline Variables & ANSIEVAL & ANSIETEM & ANSIECOM & ANSIENUM & ANSISIMA \\
\hline ANSIEVAL & $\mathbf{0 . 8 5 6}^{\mathbf{a}}$ & & & & \\
ANSIETEM & -0.403 & $\mathbf{0 . 8 9 2}^{\mathbf{a}}$ & & & \\
ANSIECOM & -0.242 & -0.097 & $\mathbf{0 . 8 8 7 ^ { \mathbf { a } }}$ & & \\
ANSIENUM & -0.389 & -0.226 & -0.288 & $\mathbf{0 . 8 8 4}^{\mathbf{a}}$ & \\
AMSISIMA & -0.045 & -0.195 & -0.356 & -0.098 & $\mathbf{0 . 9 0 1}^{\mathbf{a}}$ \\
\hline
\end{tabular}

Source: own. a: measuring sampling adequacy 
Once that factorial analysis was determined as an appropriate technique to analyze data, we proceed to examine factors and components; hence, table 6 shows the component matrix and communalities as well as eigenvalues, whose explanatory power will explain the total variance.

Table 7. Components matrix, communalities, eigenvalue and total variance

\begin{tabular}{lll}
\hline & Component 1 & Communalities \\
\hline ANSIEVAL & 0.905 & 0.818 \\
ANSIETEM & 0.893 & 0.798 \\
ANSIECOM & 0.897 & 0.805 \\
ANSIENUM & 0.909 & 0.826 \\
AMSISIMA & 0.793 & 0.629 \\
Eigenvalue & 3.876 & \\
Total Variance & $0.77511=77.51 \%$ & \\
\hline
\end{tabular}

Source: own

Based on the criterion of eigenvalue greater than 1 (3.876) the result suggests the presence of one factor (Figure 3 ), from whose explanatory power may explain the total variance in $77.51 \%$ of total variation on the data.

Furthermore, factorial weights obtained by the extraction of principal components method are shown in table 6 . The above corresponding to each factors that integrate one component, where we may see that all have a factorial weight $>0.50$, being ANSIENUM (0.909) the largest weight (anxiety towards numerical), followed by ANSIEVAL (0.905) and less factorial weight, but always observing behavior $>0.5$ is ANSISIMA (0.793). And at the side of the proportion of variance explained through the communalities, ANSIENUM (0.826) the highest value, and at the opposite extreme or lesser value is ANSISIMA (0.629)

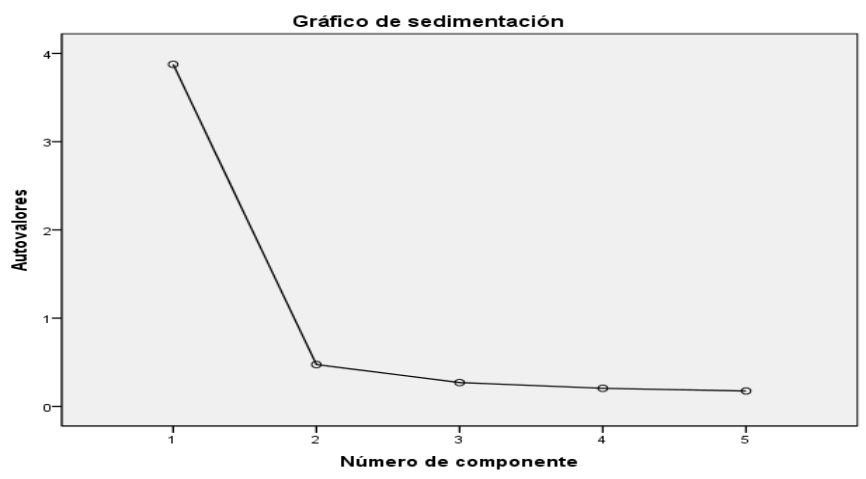

Figure 3. Scree plot

\section{Conclusions}

Education as all disciplines, need to sustain beliefs that are formed about a social phenomenon: Mathematics are part of the science, are present in the engineering, in more advanced technologies such as space flight, in modern medical techniques such as computed tomography, in meteorology, the financial studies and up to the art is influenced by mathematics, since the famous numerical discovery of Pythagoras, in the musical harmony.

Statistics has shown the low performance of students in mathematics, i.e. the results obtained through international programs such as PISA test, which reveals a problem of world court, which must be addressed by Governments since all the edges. It is not possible make judgments that lead to attack the problem if prior does not seek the truth through scientific research. As the seminal studies of Fennema and Sherman (1976) that allowed them to discover that the problem of knowledge in mathematics does not have only a cognitive or epistemological nature: it is undeniable that there are other factors such as the anxiety experienced by the person and is needed be investigated from a variety of perspectives, which gives rise to a range of possibilities by the qualities peculiar to the human being, as are its surroundings (everything around). The difference of gender, age, culture, among other variables, gives to this phenomenon, a multi contextual nature, providing the researcher infinite possibilities to deal with it. 
This research focuses in the subjective knowledge of the student, based on his belief, which is produced when the subject is convinced that, what they think is true, it would be a mistake to think that the problem of math anxiety it is purely cognitive (Pólya, 1945), the reason is far from being omnipotent, it lacks creative capacity, it must necessarily have the above information from the senses.

From the five variables that integrate the 24 items of the scale, we have that anxiety toward number operations, anxiety toward evaluation and anxiety toward understanding mathematical problems showed the highest factorial weight $(0.909,0.905$ and 0.897 respectively) in the extracted component. With this consideration, it is possible to affirm that these variables have the most important contribution to the variance of the phenomenon studied. Thus, we may observe that anxiety reaches its highest level in high school students from Tuxtepec, Oaxaca when they are evaluated, when they solve a numerical problem or when they need to understand with limited of time and space a math operation. These situations have in common that student could feel "exhibit" during the process to understand and solve a math problem, that is why it is possible that a student choose his career in order to avoid math but doesn't have the same fear to solve a number problem in real life.

This evidence might very well serve to the academic authorities in all Secondary School from Tuxtepec, Oaxaca, México, with the aim of align efforts among: its subject content (curriculum), teaching-learning strategies implemented in the educational process of mathematics teaching and teachers, who is the leading, and one of the most important parts in the process.

Finally, these results encourage us to propose the development of positive attitudes in mathematics as a primary objective in the process of teaching and learning in secondary schools in Tuxtepec, Oaxaca.

\section{Acknowledgements}

The authors are very grateful to the anonymous blind-reviewer for all suggestions, to the Universidad Cristóbal Colón and to all Junior High School in Tuxtepec Oaxaca who participated in this study, for all their help and support in develop of this research.

Authors have declared that no competing interests exist.

All authors declare that 'written informed consent was obtained from the patient (or other approved parties) for publication of this case report and accompanying images. A copy of the written consent is available for review by the Editorial office/Chief Editor/Editorial Board members of this journal.

The research is financed by Universidad Cristobal Colon (Sponsoring information)

This research is part of several empirical studies that we carry out in the southeast of Mexico. The aim was to find empirical evidence about anxiety levels toward mathematics on different grades: Elementary School, Jr. High School (middle), High School and College/undergraduate.

\section{References}

Akey, T. (2006). School context, student attitudes and behavior, and academic achievement: An exploratory analysis. Retrieved from http://www.eric.ed.gov/ERICDocs/data/ericdocs2/content_storage

Aliaga, J., \& Pecho, J. (2000). Evaluación de la actitud hacia la matemática en estudiantes secundarios [Assessment of attitude towards mathematics in secondary students.]. Revista Paradigmas, 1(1-2), 61-78.

Auzmendi, E. (1992). Las actitudes hacia las matemáticas-estadística en las enseñanzas medias y universitarias: Caracteristicas y medición [Attitudes towards mathematics-statistics in middle and university education. Features \& Measurement]. Bilbao, España: Mensajero.

Bandura, A. (1986). Social foundation of thought and action: A social cognitive Theory. Englewood Cliffs, NJ: Prentice Hall.

Belbase, S. (2010). Images, Anxieties and Attitudes toward Mathematics. College of Education. Wyoming: University of Wyoming. Retrieved from http://ezproxy.si.unav.es:2589/PDFS/ED513587.pdf

Dantzig, G. B., Orden, A., \& Wplfe, P. (1954). The Generalized Simplex Method for Minimizing a Linear Form under Linear Inequality Restraints. Rand Research Memorandum RM-1264 (April 5, 1954).

Dantzig, T. (1954). Number: The Language of Science by Dantzig.

Deci, E. L., \& Ryan, R. M. (1985). Intrinsic motivation and self-determination in human behavior. New York: Plenum. http://dx.doi.org/10.1007/978-1-4899-2271-7

Deci, E. L., \& Ryan, R. M. (2002). The paradox of achievement: The harder you push. In J. Aronson (Ed.), Improving academic achievement (pp. 59-85). Contributions of social psychology, New York: Academic 
Press.

Dehaene, S. (1999). Event-related fMRI analysis of the cerebral circuit for number comparison. Neuro-Report, in press.

Dehaene, S. (2002). El sentido numérico: Como la mente crea las matemáticas [The numerical sense: How the mind creates mathematics]. Boletín de la Asociación Matemática Venezolana, IX(1).

Dreger, R. M., \& Aiken, L. Jr. (1957). The identification of number anxiety in a college population. Journal of Educational Psychology, 48, 344-351. http://dx.doi.org/10.1037/h0045894

Enlace. (2013). Evaluación Nacional del Logro Académico en Centros Escolares [National Assessment of Academic Achievement in Schools]. Retrieved from http://www.enlace.sep.gob.mx/ba/prueba_en_linea/

Escalera-Chávez, M., García-Santillán, A., \& Venegas-Martínez, F. (2014). Confirmatory Factorial Analysis to Validity a Theoretical Model to Measure Attitude toward Statistics. Mediterranean Journal of Social Science, 5(1), 569-577. Retrieved from http://www.mcser.org/journal/index.php/mjss/article/view/1936

Eurydice. (2011). La Enseñanza de las Matemáticas en Europa, Retos Comunes y Políticas Nacionales [Teaching of Mathematics in Europe, Common Challenges and National Policies]. Red Eurydice. Retrieved from http://eacea.ec.europa.eu/education/eurydice./thematic_reports_en.php\#2011

Fennema, E., \& Sherman, J. A. (1976). Fennema-Sherman Mathematics Attitude Scale: Instruments designed to measure attitudes toward the learning of mathematics by females and males. JAS Catalog of Selected Documents in Psychology, 6, 31.

Fennema, E., \& Sherman, J. A. (1978). Sex-related differences in mathematics achievement and related factors: A further study. Journal for Research in Mathematics Education, 9, 189-203. http://dx.doi.org/10.2307/748997

Gairín, J. (1990). Las actitudes en educación. Un estudio sobre la educación matemática [Attitudes in education. A study of mathematics education]. Barcelona: Boixareu universitaria.

García-Santillán, A., Edel-Navarro, R., Chávez, M. E., Aldana, D., \& Cornejo, P. (2012). Students’ perceptions toward financial mathematics teaching process: An empirical study on engineering undergraduate students. International Journal of Business and Social Science, 3(14), 73-82.

García-Santillán, A., Escalera, M., Camarena, P., \& García, A. M. (2012). Structural equations modeling to measure variables involved in the interaction between mathematics and computer: An empirical study in undergraduate students. International Journal of Humanities and Social Science, 2(24), 6-13.

García-Santillán, A., Escalera-Chávez, M., \& Rangel, A. C. (2012). Variables to measure interaction among mathematics and computer through structural equation modeling. Journal of Applied Mathematics and Bioinformatics, 2(3), 51-67.

García-Santillán, A., Escalera-Chávez, M., \& Venegas-Martínez, F. (2013). Principal components analysis and Factorial analysis to measure latent variables in a quantitative research: A mathematical theoretical approach. Bulletin of Society for Mathematical Service and Standars, 2(3), 3-14.

García-Santillán, A., Escalera-Chávez, M., \& Venegas-Martínez, F. (2013). How is perceived the financial mathematics teaching process mediated by ICT: Differs by type of universities? International Journal of Mathematical Archives, 4(8), 201-209.

García-Santillán, A., Escalera-Chávez, M., Rangel, A. C., \& Morales-López, S. (2013). Attitude and behavioral among Students, Computers and Mathematics. British Journal of Education, 1(1), 14-32.

García-Santillán, A., Moreno, E., Carlos, J., Zamudio, J., \& Garduño, J. (2012). Cognitive, Affective and Behavioral Components that explain Attitude toward Statistics. Journal of Mathematics Research, 4(5), 8-16. http://dx.doi.org/10.5539/jmr.v4n5p8

García-Santillán, A., Venegas-Martínez, F., \& Escalera-Chávez, M. (2013). An exploratory factorial analysis to measure attitude toward statistic. Empirical study in undergraduate students. International Journal of Research and Reviews in Applied Sciences, 14(2), 356-366.

García-Santillán, A., Venegas-Martínez, F., \& Escalera-Chávez, M. (2013). Attitude toward statistics in college students: Differs among public and private universities? International Journal of Mathematical Archives, $4(5), 229-234$.

García-Santillán, A., Venegas-Martínez, F., Escalera-Chávez, M., \& Córdova-Rangel, A. (2013). Attitude towards statistics in engineering college: An empirical study in public university (UPA). Journal of Statistical and Econometric Methods, 2(1), 43-60. 
Gomez-Chacon, I. M. (1997). La alfabetización emocional en educación matemática [Emotional literacy in mathematics education]. Revista Uno, 13, 13-15.

Gomez-Chacon, I. M. (1999). Procesos de aprendizaje en matemáticas con poblaciones de fracaso escolar en contextos de exclusión social. Las influencias afectivas en el conocimiento de las matemáticas [Learning processes Mathematics with populations of scholastic failure in contexts of social exclusion. Affective influences in the knowledge of mathematics]. En premios Nacionales de Investigación e Innovación Educativa 1998, Colección Investigación, Ministerio de educación y Cultura-CIDE, Madrid, 333-358.

Gomez-Chacon, I. M. (2000). Matemática emocional [Emotional mathematics]. Madrid: Narcea.

Hancock, D. R. (2001). Effects of test anxiety and evaluative threat on students 'achievement and motivation. Journal of Educational Research, 94(5), 284-290. http://dx.doi.org/10.1080/00220670109598764

Ho, H., Senturk, D., Lam, A. G., Zimmer, J. M., Hong, S., Okamoto, Y., ..., Wang, C. (2000). The affective and cognitive dimensions of math anxiety: A cross-national study. Journal for Research in Mathematics Education, 31(3), 362-379. http://dx.doi.org/10.2307/749811

Jennison, M., \& Beswick, K. (2010). Student Attitude, Student Understanding and Mathematics Anxiety. In M. Goos, R. Brown, \& Y. K. Makar (Eds.), Navigating currents and charting directions (pp. 280-288). Proceedings of the 33rd annual conference of the Mathematics Education Research Group of Australasia. Freemantle, Western Australia.

Karimi, A., \& Venkatesan, S. (2009). Mathematics Anxiety, Mathematics Performance and Academic Hardiness in High School Students. International Journal of Educational Sciences, 1(1), 33-37.

Lam, A. G., Zimmer, J. M., Hong, S., \& Yukari, O. (2000). The affective and Cognitive Dimensions of Math Anxiety: A Cross-national Study. Journal for Research in Mathematics Education.

Lord, P. Et. Al. (2005). International Review of Curriculum and Assessment Frameworks. Learner Motivation 3-19: An international Perspective. National Foundation for Educational Research. Retrieved from http://www.ica.org.uk/pdf/learner\%20motivation\%20final\%20version\%20for\%20web.pdf

Magalhaes, A. (2007). Ansiedad face aos Testes. Género e rendimiento Académico: Um estudo no Ensino Básico [Anxiety to the face of evidence. Gender and academic performance: A study in formal education]. Tese de mestrado. Faculdade de Psicología e Ciencias da Educacao. Universidade do Minho

Mandler, G. (1989). Affect and learning: Causes and consequences of emotional interactions. In D. B. McLeod, \& V. M. Adams (Eds.), Affect and Mathematical Problem Solving: A new Perspective (pp. 3-19). Nueva York: Springer-Verlag.

Mcleod, D. (1989). Beliefs, attitudes and emotions: New views of affect in mathematics education. In D. B. McLeod, \& V. M. Adams (Eds.), Affect and Mathematical Problem Solving: A new Perspective (pp. 245-258). Nueva York: Springer-verlag.

Mcleod, D. B. (1992). Research on affect in mathematics education: A reconceptualization. Handbook of Research on Mathematics Teaching and Learning (pp. 575-596). New York: Macmillan and NCTM.

Mcleod, D. B. (1994). Research on affect and mathematics learning in the JRME: 1970 to the present. Journal for Research in mathematics education, 25(6), 637-647. http://dx.doi.org/10.2307/749576

Mcleod, D. B., \& Adams, V. M. (Eds.). (1989). Affect and Mathematical Problem Solving: A New Perspective. New York: Springer-Verlag. http://dx.doi.org/10.1007/978-1-4612-3614-6

Miranda, A., Fortes, C., \& Gil, M. D. (2000). In A. Málaga (Ed.), Dificultades del aprendizaje de las matemáticas. Un enfoque evolutivo [Learning difficulties in mathematics. An evolutive approach].

Mousoulides, N., \& Philippou, G. (2005). Students' motivational beliefs, self-regulation and mathematics achievement. In H. L. Chick, \& J. L. Vincent (Eds.), Proceedings of the $29^{\text {th }}$ Conference of the International Group for the Psychology of Mathematics Education (PME) (pp. 321-328). Melbourne, Australia: PME. Retrieved from http://www.emis.de/proceedings/PME29/PME29RRPapers/PME29Vol3Mousoulides Philippou.pdf

Muñoz, J. M., \& Mato, M. D. (2007). Elaboración and estructura factorial de un cuestionario para medir la ansiedad hacia las matemáticas en alumnos de educación secundaria obligatoria [Elaboration and factorial structure of an questionnaire to measure math anxiety in students of compulsory secondary education]. Revista Galego-portuguesa de Psicoloxia e Eduación, 14(11), 221-231.

Perina, K. (2002). The sum of all fears. Psychology Today, 35(6), 19. 
Pintrich, P. R. (1999). The role of motivation in promoting and sustaining self-regulated learning. International Journal of Educational Research, 31, 459-470. http://dx.doi.org/10.1016/S0883-0355(99)00015-4

Pirls-Timss. (2011). Estudio Internacional de progreso en comprensión lectora, matemáticas y ciencias [International study for progress on reading comprehension, mathematics and science]. IEA, 1. Informe Español. Ministerio de educación, cultura y deporte. Madrid. 2012.

Pisa. (2012). Informe Internacional [International Report]. Boletín de educación educaINNE. Ministerio de educación cultura y deporte. Retrieved from https://www.mecd.gob.es/inee/estudios/pisa.html

Polya, G. (1945). How to solve it, Nueva York, USA, Doubleday (version castellana: Cómo plantear y resolver problemas, México, Trillas, 1972).

Richardson, F. C., \& Suinn, R. M. (1972). The Mathematics anxiety rating scale: Psychometric data. Journal of Counseling Psychology, 19(6), 551-554. http://dx.doi.org/10.1037/h0033456

Sandman, R. (1980). The mathematics attitude inventory: Instrument and user's manual. Journal for research in Mathematics Education, 11, 148-149. http://dx.doi.org/10.2307/748906

Schoenfeld, A. (1992). Learning to think mathematically: Problem solving, metacognition and sense making in mathematics. In D. A. Grouws (Ed.), Handbook of research on mathematics teaching and learning. A project of the National Council of teachers of mathematics, Nueva York, Estados Unidos, Macmillan.

Siemon, D., Virgona, J., \& Cornielle, D. (2001). The Middle Years Numeracy Research Project: 5-9, Final Report: Department of Education, Employment and Training, Victoria, Catholic Education Commission of Victoria and Association of Independent Schools of Victoria.

Tobias, S., \& Weissbrod, C. (1980). Anxiety and mathematics: An update. Harvard Educational Review, 50(1), 63-70.

Utsumi, M. C., \& Mendes, C. R. (2000). Researching the attitudes towards mathematics in basic education. Educational Psychology, 20(2), 237-243. http://dx.doi.org/10.1080/713663712

Watt, H. M. G. (2000). Measuring attitudinal change in mathematics and English over $1^{\text {st }}$ year of junior hig scholl: A multidimensional analysis. The journal of Experimental Education, 68(4), 331-361. http://dx.doi.org/10.1080/00220970009600642

Whitley, T. W. (1979). The effects of individualized Instruction on the attitudes of Middle School Pupils. Journal of Educational Research, 75, 188-193.

Wigfield, A., \& Meece, J. L. (1988). Math anxiety in elementary and secondary school students. Journal of educational Psychology, 80, 210-216. http://dx.doi.org/10.1037/0022-0663.80.2.210

\section{Note}

Note 1. Muñoz, J. M., \& Mato, M. D. (2007). Elaboración and estructura factorial de un cuestionario para medir la ansiedad hacia las matemáticas en alumnos de educación secundaria obligatoria [Elaboration and factorial structure of a questionnaire to measure math anxiety in students of compulsory secondary education]. Revista Galego-portuguesa de Psicoloxia e Eduación, 14(11), 221-231.

\section{Copyrights}

Copyright for this article is retained by the author(s), with first publication rights granted to the journal.

This is an open-access article distributed under the terms and conditions of the Creative Commons Attribution license (http://creativecommons.org/licenses/by/3.0/). 